\title{
AN ANALYSIS OF MURALS IN DIFFERENT REGIONS OF RAJASTHAN AND ITS APPLICATION IN INTERIOR AND ARCHITECTURE
}

\author{
DR. KAJAL THAKURIYA ${ }^{\mathbf{1}} \boldsymbol{\&}$ AR. MANISH THAKURIYA ${ }^{\mathbf{2}}$ \\ ${ }^{1}$ Associate Professor, Vivekananda Global University, Jaipur, Rajasthan, India \\ ${ }^{2}$ Architect, Vivekananda Global University, Jaipur, Rajasthan, India
}

\begin{abstract}
The idea of having painted walls goes back to pre-historic times. The primitive man used to decorate his cave dwelling with red and black stone, which are still available in some areas connected with primitive culture. And, this tradition is also continuing till today but the form; material and motive has changed from that period. The main objective of this paper is to study the murals, its historical background and its use in current architecture and interiors. All the historical monuments stand as a record of greatest tribute paid to emperors; these are enlivened with brilliant mural paintings. The importance of mural can be understood by seeing all the traditional buildings embellished by wall paintings. While in modern contemporary period, mural found importance as a work of art. The study and analysis of murals shows the importance of murals in different periods and described their existence in various forms in different periods and found its usage in current practices as well. The study of color schemes, materials and forms developed in different periods were adopted according to their different traditions and local materials. The most significant part of this paper is to highlight mural as an important art form in architectural spaces, interior spaces as well as in human lives.
\end{abstract}

KEYWORDS: Murals, Traditional, Contemporary, Artists Interior \& Architecture

Received: Mar 21, 2020; Accepted: Apr 11, 2020; Published: Jun 01, 2020; Paper Id.: IJESRJUN20205

\section{INTRODUCTION}

The word mural means "of a wall," It is necessary to understand that unlike a painting which is free in expression, a mural has to base itself on the reality of the very wall itself. Satish Gujral says that "Painting and mural are the two sides of a coin," "According to Keshav Malik, the relation between painting, sculpture and architecture is a pertinent one when one thinks of the mural. All monuments belonging to ancient civilisations are examples of close collaboration between these arts. The great muralists Satish Gujral explains the mural and said that there is perhaps a wrong notion both on the part of the public and amongst artists as to what mural really is. Some people seem to think that any painting enlarged on a wall can be described as a mural. A short story cannot turn into a novel. Technically, mural painting is a category in itself. It is strictly neither a part of painting nor of architecture or of sculpture, though it employs elements of all the three. Like for instance, a film which may be based on a short story, on music, on a play, but which unites all three produces an art form that is essentially cinematic. Basically mural is not a single element, it includes whole environment and it is a mixture of all arts. It is a part of total environment and social activity. From prehistoric to till date evidences of relation of mural with mankind and their living spaces are found in different ways. Although important subject matters, colour schemes and techniques have been changed with different time periods. But the bonding of human activities with mural is seen consistently. To understand the role of mural in human lives the study of historical journey will be very helpful. 


\section{JOURNEY OF MURAL WITH HUMAN SHELTER}

In the Indian context, historical journey of mural have different stages and development. Mural art began with the existence of human being and their shelter. Initially; caves were used as a shelter and mural were the part of those rocks. Mural in the form of rock paintings was in the existence from the human origin first reported the discovery of rock art in India, which was made by Archibald Carlleyle, first assistant in the archaeological office, at Sohagi Ghat in Mirzapur district in the present state of Uttar Pradesh in 1867-68. Time period of prehistoric art was from 30000 B.C. to 50 B.C. The largest accumulation of Indian rock paintings, nearby two third, are located in quartzitic, sandstone belt of central India, principally in present state of Madhya Pradesh and also in the state of Rajasthan and Uttar Pradesh and North. The earliest references to the mural art in India goes back to the Rig Vedic period. ${ }^{4}$ Panini has also referred to it probably in between $8^{\text {th }}$ century B.C. to $4^{\text {th }}$ century B.C. The mural painting in India has a long history and testifies to the soundness and efficacy of the methods and processes devised by our artists of bygone ages. We also find few scantly references to the Indian art of mural in Purnshmegh. It is generally assumed that the mural in India was secular in nature and had the status of a highly recognized art object since times immemorial. The great epics of India, the Mahabharata and the Ramayana, mentions its great detail that the royal palace of Yudhisthir was well adorned with mural painting at Hastinapur at present New Delhi. The great epic of India e.g. the Balmiki Ramayan has also referred to the wall painting prevalent during these periods. Another reference of chitrashala in Balmiki Ramayan for the first time. He had also referred that the royal palaces of Kaikeyi that was adorned with wall paintings. Paintings were also done on the head of elephants and on the cheeks of ladies. But, the art of mural painting in India attained its maturity during the time of Buddha. After this prehistoric period, Ajanta murals in 50 A.D. were made in Ajanta cave. Ajanta art is the first magnificent efflorescence of the genius of Indian painting and remnants of mural-painting. Remnants of actual painting do not exist in the gap period. Ajanta itself is the solitary grandeur, for no painting has survived elsewhere, belonging to the same period. Walls, ceilings, pillars, lintels, all were embellished with the painted mural and half relief mural in Ajanta caves. Ajanta and Bagh were two great centers of Buddhist art of painting in India. In order to proclaim the message of the Buddha to these pilgrims, the monks employed artists who turned the stone walls into picture book of his life and teaching, representations from the Jatak tales illustrate his intelligence, noble character, selfless service and compassion by means of legends from his previous births. The paintings cover not only the walls and ceilings of the caves, but also a time span of seven hundred years, thus showing changes in style. At Bagh in Madhya Pradesh, another flourishing Buddhist monastery existed in the $5^{\text {th }}$ and $6^{\text {th }}$ centuries A.D. In the same way, in 'Sittanavasal' the cave temple was completely adorned with mural decorations, but what survives today are the remnants on the ceiling, capital and the upper parts of the pillars. These arts resembles to Ajanta murals. Under the powerful dynasty; there were great building activities during the $10^{\text {th }}$ and $11^{\text {th }}$ centuries in Tanjavur. The entire wall and ceiling of the magnificent Brihadisvara temple at Tanjavur were painted on a scale befitting the architectural grandeur of this great temple. In the Vijaynagar painting in south India, Jain temple of the fourteen century at Tiruparuti Kundaram, the mural painting and mural relief which was done for centuries on the walls of village huts were found. In the context of Rajasthan, from pre-historic to Rajput period to till date under the different dynasty, there are several examples of rich wall paintings and mural on the cenotaphs, ceilings, pillars and walls of the forts, temples, and other private buildings. Thus, we can say that mural art took birth with the beginning of human shelter. So, the journey of human and mural grew simultaneously. 
Table: 1 Historical Journey of Indian Murals

\begin{tabular}{|c|l|l|}
\hline Duration & \multicolumn{1}{|c|}{ Period } & \multicolumn{1}{|c|}{ Location } \\
\hline $\begin{array}{c}\text { 30,000 B.C. to } \\
\text { 10,000 B.C. }\end{array}$ & Pre-H Historic Period & M.P U.P Rajasthan Maharashtra \\
\hline $\begin{array}{c}\text { 10,000 B.C. to } \\
\text { 350A.D. }\end{array}$ & $\begin{array}{l}\text { Ramayana, Mahabharata and } \\
\text { Gupta, Mourya period }\end{array}$ & $\begin{array}{l}\text { Sri Lanka, U.P., M.P. Maharashtra } \\
\text { Rajasthan Karnataka Tamilnadu Andhra } \\
\text { Pradesh }\end{array}$ \\
\hline $\begin{array}{c}\text { 350 A.D. to } 500 \\
\text { A.D. }\end{array}$ & Buddha Period (Classical) & Ajanta \\
\hline $\begin{array}{c}578 \text { A.D. to } 579 \\
\text { A.D. }\end{array}$ & Buddha Period & Badami \\
\hline $\begin{array}{c}\text { 600 A.D. to } 625 \\
\text { A.D. }\end{array}$ & Buddha Period & Sittanavasala \\
\hline $\begin{array}{c}\text { A26.D. to } 628 \\
\text { A.D. }\end{array}$ & Buddha Period & Bagh \\
\hline $\begin{array}{c}700 \text { A.D. to } 1000 \\
\text { A.D. }\end{array}$ & Pre-medieval Period & Ellora \\
\hline $\begin{array}{c}1000 \text { A.D. to } \\
1100 \text { A.D. }\end{array}$ & Pre-medieval Period & Tanjavur \\
\hline $12^{\text {th }}$ century & Post-medieval Period & Choleshwar temple \\
\hline $13^{\text {th }}$ century & Post-medieval Period & Tirupati kundram \\
\hline $\begin{array}{c}16^{\text {th }} \text { to } 20^{\text {th }} \\
\text { century }\end{array}$ & Traditional Period & Rajasthan \\
\hline $\begin{array}{c}\text { t8 } \\
\text { century }\end{array}$ & Renaissance period & India \\
\hline $\begin{array}{c}\text { From } 19^{\text {th }} \\
\text { century }\end{array}$ & Modern contemporary period & India \\
\hline
\end{tabular}

\section{CENTERS OF MURAL IN TRADITIONAL PERIOD (RAJASTHAN)}

In the context of Rajasthan, from pre-historic to Rajput period to till date, under the different dynasty, there are several examples of rich wall paintings and mural on the cenotaphs, ceilings, pillars and walls of the forts, temples, and other private buildings. In Rajasthan, all four regions Hadauti, Dhundhar, Marwar and Mewar were the great centers of mural. Man Singh's Chhatari, Maharaja Man Singh's Palace at Mouzamabad, Mughal Gateway at Bairath, Maqdoom Shah's Tomb, Jagat Shiromani Temple, Amber, Ganesh Pol, Amber, Galta, Sisodia Rani's Palace, Shish Mahal, Dewanji ki Haveli, Chhatari of Hanuwant Singh, were the great centers in Dhudhar region. Palace of Maharao or Garh Palace,Haveli of Jhala Jalim Singh, Haveli of Devta Shridharji, Temple of Suryanarayan, Amar Niwas,Nagar Dwar, Umed mahal or Chitrashala, Chhatar mahal, Bade maharaj ka mahal, Haveli of bhav singhji,Haveli of bhatt maharaj, Haveli of Goverdhanji, Shop of Bhandari are the centres of mural in Haduati region. Dha -Bhaiji -ki-Haveli:, Bhim Vilas, Udaipur fort, Jain Mandirs of Udaipur, Dwarkadish ka Mandir, Juna mahal, Dungarpur fort, Salumbar were the centres of Mewad region . Jodhpur Fort, Sheeshmahal, Chhatari, Tija-Maji Temple, Turji-ka-Mandir, Sita Ramji-Ka-Mandir, Bikaner Fort, Rang Mahal, and Jaisalmer were the great centres in Marwar region.

Table 2: Techniques used for Making of Murals in Rajasthan

\begin{tabular}{|l|l|l|}
\hline \multicolumn{1}{|c|}{ Period/art } & \multicolumn{1}{c|}{ Location } & \multicolumn{1}{c|}{ Technique } \\
\hline Prehistoric period & Rajasthan,Kota & Stencil, relief, engraving \\
\hline $\begin{array}{l}\text { Traditional period } \\
\text { Rajputana period) }\end{array}$ & Rajasthan & Fresco secco, fresco-buono \\
\hline Modern to contemporary & Rajasthan & $\begin{array}{l}\text { All technique, mosaic, ceramic, relief, } \\
\text { inlay, terracotta, etc. }\end{array}$ \\
\hline
\end{tabular}


Table 3: Colour Schemes of Rajasthani Murals

\begin{tabular}{|l|l|}
\hline \multicolumn{2}{|c|}{ Time Period } \\
$\begin{array}{l}\text { Rajasthani Traditional period } \\
\text { Dhundhar region }\end{array}$ & Red ochre, yellow ochre, white safeda, Indian red, green, vermillion. \\
\hline Hadauti region & Golden colour, red, yellow, green, white, are prominent. \\
\hline Marwar region & Blue, gold, red, yellow. \\
\hline Mewar region & Purple, green, yellow. \\
\hline Contemporary & Random colour scheme, bright colours, as per the subject and location. \\
\hline
\end{tabular}

\section{CENTRE OF MURALS IN CONTEMPORARY PERIOD}

Mural is not bounded in any particular period; it also existed in past time as well in present contemporary period. The meaning of contemporary mural is not the modern style. It includes any type of work which is doing in present time. So the style is not bounded in particular period. It was always adopted according to the type and requirement of the place. The very important part of the research is 'contemporary murals' reflects the existence of mural in contemporary period. But in contemporary period art became an individual affair. So, centre of mural in contemporary time are the private properties, government properties and public properties.

\section{IMPORTANCE OF MURAL IN INTERIOR AND ARCHITECTURE}

Mural can express one's feelings and views without a single word. This is beautification of wall, ceiling, and pillars in supporting context of architecture. Mural conveys one's sensation to the mass through its art of expression. Mural has a power to attract concentration of mass. Mural was in existence from past time in India, for example pre-historic sketches are the proof of mural's importance during that time mural or that sketches were made for the memory, to teach lesson, hunting, and for miracle. People of that period expressed their sense and goal through the art. The another classic example of mural is Ajanta, which is well known for its mural in which tales of Buddha was depicted and today the knowledge of that time and their activities are in our memory through that fine \& unremarkable mural. So the mural found importance during that time as well. In addition to many examples, mural was found in Indus valley civilization's art, Nalanda, Santiniketan etc. All these examples of mural prove its importance of mural in the life of human being. Thus, mural has its own place in India as well as in Rajasthan. The traditional period of Rajasthan was very rich in mural as support was given to the art by patron of art. Rajput rulers of Rajasthan were art lovers and they gave support to this art. They gave patronage because of the beauty of their forts \& palaces and cities witnessed increased wall paintings and they can make publicity of their prosperity through mural. So the importance of mural for the rulers of Rajasthan is to represent their richness and it was the way by which they express their feeling for the god Krishna and his life by making painting on wall on the topic of Lord's life. Similarly to traditional period, in contemporary period, mural has also its own importance both in India and Europe. In Europe every period like, Pre-historic, Egyptian, Greek or Classical, Romanesque, Byzentine, Gothic, Renaissance, and Modern period had numerous murals. In every period, mural made its presence in different styles. One important thing that strikes in mind is that painting is able to express ideas, than what importance of mural is. Every artist defines his own view regarding it. Murals are more important for Indian circumstances than for the developed western countries. Murals come into prominence as a form of public expression and communication. In the past, a communication was limited in society. The mass media for art expression, like magazines, museums and travelling exhibitions were unknown. Whereas, these features have become usual in western societies and have resulted in what Andre Malraux calls "museums without walls". In India, there is very little difference between what societies was in earlier days and what it is now. There is hardly any art magazine with a wide circulation; museums are centralised and even in cities lack of publicity 
and literacy makes them unavailable to the common man. So, mural is necessary as an instrument for shaping the modern Indian mind. An artist, without doubt creates it in order to express his inner being. But once his ideas achieve its form, become obvious and its effect on society can be measured. Unless a society is devoid of aesthetic values, it cannot help being affected. The mind is influenced by the experience of a society's creative element. Society as a whole is affected by the direction it receives from its painters, poets, social thinkers and so on. Simply speaking, the problem before the Indian artist is not ideological. The basic problem for him is to make his expression available to those whom he means to address. For that, the mural is the answer. If art has to be alive, it has to be alive for use. If art has to be seen well, it has to go through time, not in brief weekend exposures. But there are more things to it than this. He says; environmental work can be more rewarding in the sense that it can do what a single painting or sculpture cannot aspire to do. Think of the orchestrating luminosities of stained glass in a Gothic church or of the vaulted scintillations of Byzantine mosaic or the pulsating sensuousness of sculpture in Indian cave shrine caught tantalising warp of light and darkness. Or, consider work that is more elaborately environmental and covers a whole landscape like the temple city of Angkor Thom in Cambodia.

It is in contact with this art, craft and language can be expected to grow specific physiognomies today. These reasons seem to be compelling enough. But, very few of our new murals come near formulating a new vision. It has already been stated with a reason that this needs thinking alike and working together.

\section{IMPORTANCE OF MURAL (ACCORDING TO CONTEMPORARY MURALIST)}

In the view of Kanchan Chakraberti, Experiments with mural forms a significant part of the work there. From the very beginning; it was realised that mural painting was one of the media that offered scope to the contemporary mind and temperament.

Binode Behari Mukherjee's opinion about mural's importance is the monumentality and breadth of conception, generally associated with the term 'mural' are rediscovered and reinstated in contemporary India, by Binode Behari Mukherjee. The dimensions and integration that mural work truly demands has been insufficiently dealt in modern India. Modern mural activity primarily brings the artist out of his enclosed studio, gallery or museum in to the wideness of the public edifice and exposes him for better or for worse to the public eye. This encouragement would benefit the artist of the India Republic in its arrival, which may perhaps what may be called as a new national consciousness of art. It could bring artist and laymen closer. It would involve the artist more with his countrymen for he would have to walk out from the insularity of the room, where the easel stands in to the open. It would be expected that such project would give rise to masterpieces. But, people may look twice at the walls of their public building which they had once ignored.

Keshav Malik emphasize the importance of mural and say that mural painting could play an important part in animating architectural surface. It would not be surprising if this turned out to be its ultimate ambition. It is obviously essential that the architect, the painter and the sculptor should not only work individually but whole as a team. In our epoch, we have seen that there was not a single movement without art work. That work presents the glory of those monuments and of that time. Similarly, there is a modern house with its plain walls; scanty furniture looks more attractive and soothing to our eyes along with mural. The time has come, where we try to relate painting and sculpture and design to the architecture. This at once depends on the growth of the new community a community, closely knit by ideas and yet able to preserve the private and personal. What we have is only mere beginnings to transform our outer environment. But, there are indications that the community's commitments to our visual surrounding are increasing, a goal in which architecture, the mother of all plastic arts, is yoked to its sister arts supporting and supported by them. 
Being as an adornment, the Murals are not a very important part of the building, but only something which is unique in its own. The correct placing of murals gives it value as a reciprocal gesture. The wall is dead without the picture and the picture is dead without the wall. Probably, many will argue that it is enough but that is not what the mural is meant to achieve. A great mural lives by itself; without giving life to the wall. Mural has the ability to transcend the wall along with the room. Murals are like the secondary characters in a play; which form an unobtrusive necessity to the room environment, which means clear, simple, intelligible yet aesthetically satisfying, art form that would add some new dimension to the life of those who work and live around them. These are only small beginnings and have yet to make a mark on the character of particular city. But it is necessary to bring this art form to the painters, sculptors so that they can involve along with canvas or concrete to a larger dimension. With this type of involvement general public can also contribute in an artistic manner. Murals can be counted as an important aspect or manifestation of modern Indian art in the same sense as ancient cave paintings were. Thus; mural plays a significant role in the national's aesthetic achievements. A great muralist Kripal Singh Shekhawat by giving the importance of mural he describes that mural is the result and cause of the braveness and confidence of the artist. This is a work of adventure, because it presents to the mass. According to him, apart from being an adventurous work another reason is that mural is like a blank white wall which can create the illusion of sky for birds and animals, so it should be painted by figures and different shapes, by which continuity of blank space can break out. Another importance of the mural is that, it is a huge medium to express our feelings, through which one can present whole story step by step on a single wall. This example shows that as rhythm is important in music, similarly murals are important in a space to create continuity in Interior designing.

A very senior Artist, Suresh Sharma says that mural is more important rather than just painting because its huge size attracts everyone. The importance of mural is considered by him, because it gives massage to the mass. It has permanency in it.

A young sculptor and muralist Bhupesh Kavadia says; mural can enhance the beauty of the place and architecture. A mural gives specific information about the site. He says; a muralist has great responsibility to blend mural with particular architecture and environment.

According to Shai Choyal, mural has social responsibility because it is presented to the society, it can be seen by thousands of people. Mr. Chinmay Mehta says about the importance of mural, that it can be visible from distance, it has 3D effects and it represents to the building.

Rajesh Yadav is a rising star in the field of mural, also gives his statement about the importance of mural, that mural has spiritual qualities because mural is not only for the muralist or not only for the client but it is for all people who passes through there. He asserts that publicly displayed murals are bridges of sensivity and understanding between masses and the artist. So, mural has great importance in our life. Hence after knowing the opinion of these great muralists, one can easily understand the importance of mural. Mural art is not only 'art for art's sake', but also initiate to the mass for social responsibility. It is a great medium of communication between muralist and society.

\section{CONCLUSIONS}

Hence, from early periods to the modern contemporary period buildings, absence of mural (or wall paintings) is just like a body without soul. Murals in architecture present a deep insight of social, economical, and geographical environment of that era. Mural is part of architecture that's why murals have existence in architecture from the birth of human being to till 
today. To put finally in a single sentence, I can express murals' existence in architecture by saying "Murals enhances the beauty of spaces in a building." Thus, in the conclusion I want to reiterate that a mural is a medium for interaction between society and artist, which also indicates our visual aesthetic sense.

\section{REFERENCES}

1. Wall Painting of Rajasthan, Miza Seth Pg.201

2. Wall Painting of Rajasthan, Director General, Jawahar Kala Kendra, 1998, Pg. No.27

3. Wall Painting of Rajasthan Director General, Jawahar Kala Kendra 1998 Pg.No. 36

4. Karunaratne, P. V. M. "Unstructured Clothes-No Cut, No Sew: Sustainable Dress Practices of Sri Lanka." International Journal of Humanities and Social Sciences (IJHSS) ISSN (P) (2018).

5. Wall Painting of Rajasthan Director General, Jawahar Kala Kendra 1998 Pg. No. 71

6. Chronology of Mewar Painting, Shridhar AndHare, Agam Kala prakashan, Delhi 1987 Pg. No. 109

7. Ranathunga, Gayathri Madubhani. "Learning Incubates Fashion: The Case of The Kandyan Kingdom of Sri Lanka." International Journal of Humanities and Social Sciences (IJHSS) ISSN (P) (2018).

8. Lalit kala contemporary - 14 - Piccasso's quernica - Ratan Parimoo Pg. no. 33.

9. Ansari, Amna, Maria Ansari, and Farjad Faiz. "Kashi Kari in Wazīr Khan Mosque." International Journal of History and Research (IJHR) 6.2 (2016): 1-12.

10. Lalit kala contemporary - 14 why mural, an interview with Satish Gujral by UMA Vasudev. Pg. No. 25

11. Lalit Kala contemporary - 14 though on mural, K.G. subramayan pg. No.18, 19.

12. Arbaeen, O., and Hind Mohammad. "Creating Contemporary Corset Designs, for Ladies' Clothing." International Journal of General Engineering and Technology (IJGET) 7.1 (2018): 21-34.

13. Lalit Kala contemporary - 14 modern menican painters as muralist 18, Ratan parimoo pg. No. 34

14. BAJPAI, SHALENI, and ANJALI KAROLIA. "CONTEMPORARY JACQUARD DESIGNS FOR HANDLOOM BROCADE SARIS OF VARANASI." International Journal of Textile and Fashion Technology (IJTFT) 6.1, Feb 2016, 15-24

15. A History of Fine Arts in India and the West, written by Edith Tomory, published by Orient Longman Private Ltd. in 1982, Pg. No. 743

16. Karunaratne, P. V. M. "Unstructured Clothes-No Cut, No Sew: Sustainable Dress Practices of Sri Lanka." International Journal of Humanities and Social Sciences (IJHSS) ISSN (P) (2018). 

